\title{
The rediscovery of Philippine Begonias
}

\author{
R.R. Rubite ${ }^{1}$, D.A. Madulid ${ }^{2}$
}

Key words

\section{Begonia}

Philippines

\begin{abstract}
We present the first results of a new revision of the Philippine species of Begonia, starting with the sect. Diploclinium, using field surveys in order to find as many species as possible again. Out of the 39 recorded species of sect. Diploclinium, 32 have been found back in the wild. Three new species have been discovered, as well as four possible subspecies of Begonia nigritarum (Kamel) Steud. Most species occur in a single locality and the numbers of individuals are small. With rampant logging and unchecked quarrying, many species are threatened by habitat disturbance or destruction.
\end{abstract}

Published on 30 October 2009

\section{A RENEWED SEARCH FOR PHILIPPINE BEGONIAS}

Begonias are used world-wide as ornamental plants. It is therefore surprising that the last comprehensive account of Philippine Begonia, recording 59 species (Merrill 1911) is now about a century old. Golding \& Wasshausen (2002), on Begoniaceae in general, list 104 Philippine species. Globally, c. 1500 species have been named and scientists believe there are more to be discovered. Asia, from the Himalayas to southern China and Malesia, is the secondary centre of diversity for Begonias after South America (Tebbitt 2005). In Southeast Asia, the Philippines ranks first in the diversity of endemic Begonias with 104 species, followed by Borneo (95), New Guinea (79) and Burma (57) (Hughes 2007). This confirms once more that the Philippines is correctly listed as one of the 17 nations that are 'Megadiversity countries' (Mittermeier et al. 1997).

\section{A SYSTEMATIC STUDY OF SECTION DIPLOCLINIUM}

This work forms a portion of the first author's PhD on the systematic studies on Philippine Begonia. It started with field surveys in order to find as many species as possible, returning to the type localities. Currently extensive research is conducted which include re-examination of the morphological characters and considering new features such as anatomy, palynology and molecular studies. In addition, Begonia specimens were also loaned from various herbaria. The results will provide data for a taxonomic revision of the genus Begonia in the Philippines.

The 104 Philippine species of Begonia are classified in three sections (Doorenbos et al. 1998). The majority is placed in sect. Petermannia (63) and sect. Diploclinium (39). Section Baryandra and one possible new section contain one species each. This study is limited to sect. Diploclinium, since the Philippines is the centre of Diploclinium diversity (Hughes 2007) with 39 species, followed by Thailand (15), Burma (9) and New Guinea (7) (Hughes 2007).

In the Philippines and elsewhere, Begonias are found in shaded, damp ravines, on banks and cliffs along small streams, on slopes with seepage, more rarely on the forest floor well away from water. Some are found on more or less exposed cliffs

\footnotetext{
${ }^{1}$ Department of Biology, College of Arts and Sciences, University of the Philippines Manila, Padre Faura, Manila, The Philippines.

2 Botany Division, Philippine National Museum, Taft Avenue, Manila The Philippines.
}

that dry out completely during the dry season, a few others are restricted to montane mossy forest. Most species have a very limited range, and so far have been found in a single locality with few individuals only, but $B$. manillensis A.DC., $B$. mindorensis Merr. and $B$. nigritarum (Kamel) Steud. are widely distributed. Most species have a restricted altitudinal range, but $B$. nigritarum (Kamel) Steud. extends from sea level in some regions to c. $1200 \mathrm{~m}$ elsewhere. Within $B$. nigritarum 4 subspecies may be distinguished from the following provinces: Laguna, Palawan, Panay Island and Mindanao. So far, 3 new Begonia species have been found: one in Quezon, another in Cavite and one at Panay Island. More novelties will be discovered, because so far the survey has extended only over the type localities of known species. Other localities with a suitable habitat will be visited soon. The first three years of the field survey (started December 2004) have yielded the following distribution of Begonia sect. Diploclinium around the Philippine archipelago (Table 1).

Table 1 Regional distribution of Philippine Begonia sect. Diploclinium.

\begin{tabular}{|c|c|c|}
\hline Cordillera Administrative Region & - & $\begin{array}{l}\text { B. klemmei Merr. } \\
\text { B. vanoverberghii Merr. }\end{array}$ \\
\hline Region 1 - llocos Region & 一 & B. hernandioides Merr. \\
\hline Region 2 - Cagayan Valley & - & $\begin{array}{l}\text { B. castilloi Merr. } \\
\text { B. choloroneura P.Wilkie \& Sands } \\
\text { B. fenicis Merr. } \\
\text { B. isabelensis Quisumb. \& Wassh. }\end{array}$ \\
\hline Region 3 - Central Luzon & - & B. neopurpurea L.B.Sm. \& Wassh. \\
\hline Region 4 - Calabarzon & - & $\begin{array}{l}\text { B. longinoda Merr. } \\
\text { B. rufipila Merr. } \\
\text { B. tayabensis Merr. } \\
\text { B. trichocheila Warb. }\end{array}$ \\
\hline Region 4B - Mimaropa & - & $\begin{array}{l}\text { B. coronensis Merr. } \\
\text { B. gitingensis Elmer } \\
\text { B. pinamalayensis Merr. } \\
\text { B. suborbiculata Merr. } \\
\text { B. wadei Merr. \& Quisumb. }\end{array}$ \\
\hline Region 6 - Western Visayas & - & $\begin{array}{l}\text { B. copelandii Merr. } \\
\text { B. obtusifolia Merr. } \\
\text { B. rubrifolia Merr. } \\
\text { B. serpens Merr. }\end{array}$ \\
\hline Region 8 - Eastern Visayas & - & $\begin{array}{l}\text { B. biliranensis Merr. } \\
\text { B. longiscapa Warb. }\end{array}$ \\
\hline Region 10 - Nothern Mindanao & - & $\begin{array}{l}\text { B. acuminatissima Merr. } \\
\text { B. anisoptera Merr. }\end{array}$ \\
\hline Region 13 - Caraga & - & B. elmeri Merr. \\
\hline
\end{tabular}

(๑) 2009 Nationaal Herbarium Nederland

You are free to share - to copy, distribute and transmit the work, under the following conditions:

Attribution: $\quad$ You must attribute the work in the manner specified by the author or licensor (but not in any way that suggests that they endorse you or your use of the work).

Non-commercial: You may not use this work for commercial purposes.

No derivative works: You may not alter, transform, or build upon this work.

For any reuse or distribution, you must make clear to others the license terms of this work, which can be found at http://creativecommons.org/licenses/by-nc-nd/3.0/legalcode. Any of the above conditions can be waived if you get permission from the copyright holder. Nothing in this license impairs or restricts the author's moral rights. 


\section{HORTICULTURAL AND MEDICAL POTENTIAL AND THREATS}

Its beautiful foliage and ornamental flowers have made Begonia a popular ornamental world-wide. In some cases wild species are taken into cultivation, but over 10000 artificial hybrids have been registered already. From the native species of the Philippines $B$. colorata Warb. and B. luzonensis Warb. are already in cultivation. We feel that more Philippine species are sufficiently attractive to be used as ornamentals, and that they could also be used as parents for new hybrids. So far, few attempts to cultivate the native species have been made in the Philippines. The chief reason may be that in and around Metro Manila the climatic conditions are not especially favourable to cultivate species that require a relatively high humidity. Local people report that some species are edible, while others are being used as a medicine. This, too, needs to be explored. But the survival of Begonia in the wild hangs in the balance for similar reasons. Logging of our forests causes the local climate to dry out. The Philippine forests, and with them the herbaceous forest plants, are rapidly disappearing (Walpole 1999). Even if the riparian environment is spared immediate destruction, an increased silt load in the stream beds will affect the places where many Begonia grow: on rock surfaces and boulders. Limestone hills, another preferred habitat by Begonia species, are threatened by uncontrolled quarrying. The facts that many species are known for a single locality, or from very few localities, and that the populations tend to be small, only compounds the problem.

\section{CONCLUSIONS}

Philippine Begonia is threatened by habitat change or destruction, and several species are likely to become extinct in the wild. Ex-situ conservation could save some, and promoting Philippine Begonia as ornamentals could help. Their potential as food plants and their medicinal value needs to be explored.

Acknowledgements I would like to thank the Flora Malesiana VII Organizing Committee for accepting my paper for presentation and for the financial support for my participation to the symposium; the University of the Philippines, Manila for allowing me to participate in the symposium and for financial support; the Academia Sinica through Dr Ching I Peng, of the Research Center for Biodiversity, for the financial support in my field work and for the beautiful excellent copies of Begonia photographs; the many Filipino families that have accommodated me, helped me and guided me through the different forests of the Philippine islands.

\section{REFERENCES}

Doorenbos J, Sosef MSM, De Wilde JJFE. 1998. The sections of Begonia. Wageningen Agricultural University, The Netherlands.

Golding J, Wasshausen DC. 2002. Begoniaceae, 2nd ed. Smithsonian Institution Contributions from the United States National Herbarium Vol. 43: 1-289.

Hughes M. 2007. Southeast Asian Begonia Database. Royal Botanic Garden, Edinburgh. Available through: http://elmer.rbge.org.uk/Begonia/

Merrill ED. 1911. The Philippine species of Begonia. Philippine Journal of Science. Section C, Botany: 369-406.

Mittermeier RA, Gil PR, Mittermeier CG. 1997. Megadiversity: Earth's biologically wealthiest nations. Cemex, Monterrey, Mexico.

Tebbitt M. 2005. Begonias, cultivation, identification and natural history. Timber Press, Oregon.

Walpole P. 1999. Decline of the Philippines forest map and book. Environmental Science for Social Change ESSC, Quezon City, Philippines. 